\title{
Associations between daily mortalities from respiratory and cardiovascular diseases and air pollution in Hong Kong, China
}

\author{
T W Wong, W S Tam, T S Yu, A H S Wong
}

See end of article for authors' affiliations

Correspondence to: Professor T W Wong, Department of Community and Family Medicine, The Chinese University of Hong Kong, 4/F School of Public Health, Prince of Wales Hospital, Shatin, N T, Hong Kong; twwong@cuhk.edu.hk

\begin{abstract}
Objective: To investigate the association between ambient concentrations of air pollutants and respiratory and cardiovascular mortalities in Hong Kong.

Methods: Retrospective ecological study. A Poisson regression of concentrations of daily air pollutants on daily mortalities for respiratory and cardiovascular diseases in Hong Kong from 1995 to the end of 1998 was performed using the air pollution and health: the European approach (APHEA) protocol. The effects of time trend, seasonal variations, temperature, and humidity were adjusted. Autocorrelation and overdispersion were corrected. Daily concentrations of nitrogen dioxide $\left(\mathrm{NO}_{2}\right)$, sulphur dioxide $\left(\mathrm{SO}_{2}\right)$, ozone $\left(\mathrm{O}_{3}\right)$, and particulate matter $<10 \mu \mathrm{m}$ in aerodynamic diameter $\left(\mathrm{PM}_{10}\right)$ were averaged from eight monitoring stations in Hong Kong. Relative risks (RRs) of respiratory and cardiovascular mortalities (per $10 \mu \mathrm{g} / \mathrm{m}^{3}$ increase in air pollutant concentration) were calculated.

Results: Significant associations were found between mortalities for all respiratory diseases and ischaemic heart diseases (IHD) and the concentrations of all pollutants when analysed singly. The RRs for all respiratory mortalities (for a $10 \mu \mathrm{g} / \mathrm{m}^{3}$ increase in the concentration of a pollutant) ranged from 1.008 (for $\mathrm{PM}_{10}$ ) to 1.015 (for $\mathrm{SO}_{2}$ ) and were higher for chronic obstructive pulmonary diseases (COPD) with all pollutants except $\mathrm{SO}_{2}$, ranging from 1.017 (for $\mathrm{PM}_{10}$ ) to 1.034 (for $\mathrm{O}_{3}$ ). RRs for IHD ranged from 1.009 (for $\mathrm{O}_{3}$ ) to 1.028 (for $\mathrm{SO}_{2}$ ). In a multipollutant model, $\mathrm{O}_{3}$ and $\mathrm{SO}_{2}$ were significantly associated with all respiratory mortalities, whereas $\mathrm{NO}_{2}$ was associated with mortality from IHD. No interactions were detected between any of the pollutants or with the winter season. A dose-response effect was evident for all air pollutants. Harvesting was not found in the short term.

Conclusions: Mortality risks were detected at current ambient concentrations of air pollutants. The associations with the particulates and some gaseous pollutants when analysed singly were consistent with many reported in temperate countries. $\mathrm{PM}_{10}$ was not associated with respiratory or cardiovascular mortalities in multipollutant analyses.
\end{abstract}

M any time series studies on the effects of variations in daily air pollutants on mortalities and morbidities have been reported in the United States and in Europe. ${ }^{1-6}$ The role of particulates has been the focus of the research, and the associations have been found between total suspended particulates and particulates less than $10 \mu \mathrm{m}$ in aerodynamic diameter $\left(\mathrm{PM}_{10}\right)$ and all mortalities and those caused by respiratory and cardiovascular diseases. ${ }^{23-11}$ Associations have also been reported with gaseous air pollutants-namely, ozone $\left(\mathrm{O}_{3}\right){ }^{4}{ }^{12}$ nitrogen dioxide $\left(\mathrm{NO}_{2}\right),{ }^{4}$ sulphur dioxide $\left(\mathrm{SO}_{2}\right),{ }^{5} 11^{13} 14$ and carbon monoxide (CO) ${ }^{14}{ }^{15}$ Compared with the particulates, the relations between gaseous pollutants and mortalities are less consistent. Mortality has been shown to be associated with climate, ${ }^{16}$ and its interaction with air pollutants have been reported in several European countries. ${ }^{15}{ }^{17}$ In Asia, few such studies have been conducted except in northern China (Beijing) and Korea. ${ }^{78}{ }^{19}$ The relations between seasons and air pollutants are likely to differ in tropical climates. Studies from tropical countries are scarce, possibly due to the lack of credible data. Hong Kong is a densely populated coastal city in southern China with 6.8 million people in a land area of about $1000 \mathrm{~km}^{2}$. Summers are hot and humid, whereas winters are typically mild and dry. A large proportion of the population live in high rise buildings in close proximity to road traffic, a major source of air pollutants. Diesel vehicles contribute a substantial proportion of respirable particulates. Concentrations of $\mathrm{PM}_{10}, \mathrm{NO}_{2}$, and $\mathrm{O}_{3}$ are higher than those in major cities in the United States, Western Europe, and some Asian countries such as Singapore and Japan, whereas $\mathrm{SO}_{2}$ and $\mathrm{CO}$ concentrations are comparatively low. ${ }^{20}$ Air pollutants are monitored systematically over most districts. The methods and quality of data are comparable with standards in many developed countries. A vigorous validation procedure of the air pollutant measurements is followed. Mortality statistics are comprehensive and systematically validated by the health authority. Owing to the relatively high concentrations of particulates and the oxidant pollutants $\left(\mathrm{NO}_{2}\right.$ and $\left.\mathrm{O}_{3}\right)$ in Hong Kong and the proximity of the residences to the pollution source compared with western cities, an investigation into the association between the air pollutants and health outcomes is warranted. We have reported an association between daily hospital admissions and air pollutants. ${ }^{21}$ To investigate the association between air pollution and mortality, and to compare the results with our previous findings and those reported elsewhere, we performed a time series analysis on concentrations of air pollutants and daily mortality data for respiratory and cardiovascular diseases over a 4 year period from 1995-8.

\section{MATERIALS AND METHODS \\ Mortality data}

Daily mortality data between 1995 and 1998 were obtained from the Census and Statistics Department. Mortality data covered all deaths reported in Hong Kong, and were coded

Abbreviations: APHEA, air pollution and health; the European approach; $\mathrm{PM}_{10}$, particulate matter $<10 \mu \mathrm{m}$ in aerodynamic diameter; IHD, ischaemic heart diseases; COPD, chronic obstructive pulmonary diseases 
according to the 9 th revision of the international classification of diseases (ICD). Daily time series datasets were constructed for mortalities from "all diseases of the respiratory system" (ICD 461-519) and its subsets, chronic obstructive pulmonary diseases (COPD, ICD 490-496) and pneumonia and influenza (ICD 480-7). Daily datasets were also constructed for mortalities from "all diseases of the cardiovascular system" (ICD 390459 ) and its subsets, ischaemic heart disease (IHD, ICD 410-414) and cerebrovascular disease (ICD 430-8).

\section{Air quality and weather data}

Air pollution data between 1995 and 1998 were obtained from the Environmental Protection Department. Hourly concentrations of four air pollutants: $\mathrm{SO}_{2}, \mathrm{NO}_{2}, \mathrm{PM}_{10}$, and $\mathrm{O}_{3}$ were monitored in eight monitoring stations interspersed in different districts of Hong Kong using pulsed fluorescence, gas phase chemiluminescence, tapered element oscillating microbalance, and ultraviolet absorption, respectively. ${ }^{20}$ Twenty four hour mean concentrations of $\mathrm{NO}_{2}, \mathrm{PM}_{10}$, and $\mathrm{SO}_{2}$ were calculated. As the formation of $\mathrm{O}_{3}$ is dependent on sunlight, a daytime (09001700) 8 hour mean concentration of $\mathrm{O}_{3}$ was used for analysis. ${ }^{22}$ In view of the low ambient concentration of CO in Hong Kong, monitoring of $\mathrm{CO}$ has been confined to only one station in recent years. We have therefore excluded CO from our study. Daily mean temperatures and relative humidity for the same period were obtained from the Hong Kong Observatory.

\section{Statistical analysis}

A Poisson regression model was constructed in accordance with the air pollution and health: the European approach (APHEA) protocol. ${ }^{22}$ The following terms were included to construct the core model: day of the time series $(\mathrm{t})$, days of the week, trigonometric functions to control for seasonal variations $(\sin 2 \mathrm{k} \pi \mathrm{t} / 365$ and $\cos 2 \mathrm{k} \pi \mathrm{t} / 365$, where $\mathrm{k}=1,2,3,4$, and 6, represent cycles of 12 , $6,4,3$, and 2 months respectively), temperature and humidity. ${ }^{21-23}$ To control for overdispersion, the covariance matrix was modified by multiplying the dispersion parameter $\phi$, and the scaled deviance and log likelihoods used in likelihood ratio tests were divided by $\phi$. The function obtained by dividing a log likelihood for the Poisson distribution by a dispersion parameter is an example of a quasi-likelihood function. ${ }^{24} 25$ To control for autocorrelation, the autocorrelation functions plot of the residuals was examined and significant terms, up to lag day 7 , were retained in the model. ${ }^{23}{ }^{26}$ Different pollutants may affect mortality with variable time lags. To test the influence of an individual pollutant on mortality, a single pollutant model was constructed for each of the four pollutants by adding its daily concentration to the core model. The best fitting lag period of each pollutant was found by testing its concentration on single lag days and on cumulative lag days (moving averages). Lag days from 0 ( same day) to 5 ( 5 days before) were tested for $\mathrm{O}_{3}$; lag days from 0 to 3 were tested for the other three pollutants. The lag period used to construct the model that gave the smallest Akaike's information criterion value was then selected for each pollutant. ${ }^{27}$ The relative risk (RR) and its 95\% confidence intervals (95\% CIs) for a $10 \mu \mathrm{g} / \mathrm{m}^{3}$ increase in the concentration of each pollutant were then calculated. To study the combined effects of the pollutants, multipollutant models were constructed. Firstly, all four pollutants (as continuous variables) were entered into the core model irrespective of significance. Non-significant $(p \geqslant 0.05)$ terms were then successively removed from the model by a process of backward elimination, until only the significant terms remained. Owing to the non-trivial correlation of some pollutants, a pairwise approach was adopted as in the APHEA protocol if more than one pollutant seemed to be associated with the outcome, the associations with one pollutant stratified by the level of the other pollutant was sought. ${ }^{22}$ With this approach, we explored the interaction between different pollutants by analysing each pair of pollutants using one as a continuous variable and the other as high and low concentrations dichotomised by the median, and their interaction term (between a pollutant and a high concentration of another pollutant). The influence of the concentration of a pollutant (expressed as a continuous variable) on a high and low concentration of another pollutant was then studied. ${ }^{22} 23$ Interaction was considered to be present when the $\mathrm{p}$ value of the interaction term was less than 0.05. As an ambient temperature has a significant influence on mortality, ${ }^{16}$ we also explored the possible interaction of cold seasons (December to February, when the mean monthly temperature was below $20^{\circ} \mathrm{C}$ ) with the effects of the air pollutants by introducing a dummy variable for season in the model. ${ }^{22}$ To investigate dose-response relations, we derived from the single pollutant models the respective RRs of daily deaths by pollutant concentrations categorised into deciles with the lowest decile as reference. ${ }^{2}$

Harvesting, a hypothesis that a high death toll on one day due to air pollution would deplete the pool of vulnerable people and result in fewer deaths on succeeding days, was investigated according to the procedure described by Spix et al.$^{28}$ In short, the coefficients of the interaction between the mean daily mortalities on the previous $k$ days (where $k$ ranged from 2 to 21 ) and each of the pollutants were checked. Harvesting was considered to be present if any of the coefficients was significantly negative.

\section{RESULTS}

During the 4 years, there were 128229 deaths of which 58347 $(46 \%)$ were caused by respiratory and circulatory diseases. Table 1 shows the daily number of deaths by cause and the

Table 1 Summary statistics of daily numbers of deaths, concentrations of pollutants $\left(\mu \mathrm{g} / \mathrm{m}^{3}\right)$, and weather data

\begin{tabular}{llllllll}
\hline & Mean & SD & Min & $25 \%$ & Median & $75 \%$ & Max \\
\hline Causes of death $(\mathrm{n}):$ & & & & & & & \\
All respiratory diseases & 17 & 5 & 3 & 13 & 17 & 20 & 33 \\
Chronic obstructive pulmonary diseases & 6 & 32 & 0 & 4 & 5 & 7 & 19 \\
Pneumonia and influenza & 10 & 4 & 1 & 8 & 10 & 13 & 24 \\
All cardiovascular diseases & 23 & 7 & 7 & 19 & 22 & 27 & 53 \\
Ischaemic heart disease & 9 & 3 & 1 & 6 & 9 & 11 & 29 \\
Cerebrovascular disease & 9 & 3 & 0 & 6 & 8 & 11 & 22 \\
Air pollutants $\left(\mu \mathrm{g} / \mathrm{m}^{3}\right):$ & & & & & & & \\
$\mathrm{NO}_{2}$ & 56.40 & 19.24 & 15.29 & 43.29 & 54.19 & 68.10 & 151.5 \\
$\mathrm{PM}_{10}$ & 51.53 & 24.79 & 14.05 & 31.58 & 45.90 & 66.51 & 163.79 \\
$\mathrm{O}_{3}$ & 33.93 & 23.15 & 0.3 & 15.92 & 29.29 & 49.67 & 168.93 \\
$\mathrm{SO}_{2}$ & 16.68 & 11.59 & 1.05 & 8.58 & 13.97 & 21.27 & 90.06 \\
$\mathrm{Weather} \mathrm{variables}_{\text {Temperature }}$ & 23.4 & 5.0 & 6.9 & 19.2 & 24.6 & 27.6 & 31.3 \\
Humidity & 78.1 & 10.4 & 31 & 74 & 79 & 85 & 97 \\
\hline
\end{tabular}


Table 2 Correlation between pollutants and weather variables

\begin{tabular}{|c|c|c|c|c|c|c|}
\hline & $\mathrm{SO}_{2}$ & $\mathrm{NO}_{2}$ & $\mathrm{PM}_{10}$ & $\mathrm{O}_{3}$ & Temperature & Humidity \\
\hline $\begin{array}{l}\mathrm{SO}_{2} \\
\mathrm{NO}_{2} \\
\mathrm{PM}_{10} \\
\mathrm{O}_{3} \\
\text { Temperature } \\
\text { Humidity }\end{array}$ & 1 & $\begin{array}{l}0.438 \\
1\end{array}$ & $\begin{array}{l}0.344 \\
0.780 \\
1\end{array}$ & $\begin{array}{l}-0.073 \\
0.413 \\
0.538 \\
1\end{array}$ & $\begin{array}{l}0.186 \\
-0.346 \\
-0.319 \\
-0.045 \\
1\end{array}$ & $\begin{array}{l}-0.089 \\
-0.341 \\
-0.524 \\
-0.530 \\
0.227 \\
1\end{array}$ \\
\hline
\end{tabular}

pollutant concentrations. The Pearson's correlation coefficients between air pollutants and meteorological variables are presented in table 2. After fitting the core model, residuals were plotted against the predicted values for diagnostic checking. No cyclical pattern could be discerned in the residual plot. Table 3 summarises the RRs of daily deaths for different disease categories. The lag days for the pollutants that fitted the model best for all respiratory diseases varied for different pollutants, ranging from 1 to 2 single lag days and 0 to 1 cumulative lag days. For all cardiovascular diseases, the "best lag" ranged from 0 to 2 single lag days and up to 0 to 2 cumulative lag days. The overdispersion parameter $(\phi)$ was 1.14 and 1.09 respectively for respiratory and cardiovascular diseases. The autocorrelation coefficients $(r)$ of the models ranged from 0.005 to 0.052 . For all four pollutants, there was a significant increase in mortality for respiratory diseases that ranged from $0.8 \%$ to $1.5 \%$ per $10 \mu \mathrm{g} / \mathrm{m}^{3}$ increase in concentration of pollutant. For COPD, the risks were higher and significant for all pollutants except $\mathrm{SO}_{2}$. For pneumonia and influenza, the RRs were significant for $\mathrm{NO}_{2}$ and $\mathrm{SO}_{2}$ only. For all cardiovascular diseases and cerebrovascular diseases, the RRs for the best fitting lag days of all four pollutants were non-significant. A significant increase in mortality from IHD, ranging from $0.9 \%$ to $2.8 \%$, was associated with a $10 \mu \mathrm{g} / \mathrm{m}^{3}$ increase in the concentration of all four pollutants.
In the multipollutant model for all respiratory mortalities, $\mathrm{SO}_{2}(\mathrm{RR}=1.015)$ and $\mathrm{O}_{3}(\mathrm{RR}=1.010)$ remained after eliminating the non-significant pollutants (table 4). In the three and four pollutant models, $\mathrm{O}_{3}$ was the only significant pollutant. The RR of $\mathrm{O}_{3}$ was stable in all three models, and similar in magnitude to that in the single pollutant model. For COPD, $\mathrm{O}_{3}$ was the only significant pollutant in the two, three and four pollutant models, with RRs slightly lower than in the single pollutant model. For pneumonia and influenza, $\mathrm{SO}_{2}$ was significant after eliminating non-significant terms from the model. For IHD mortalities, $\mathrm{NO}_{2}$ was the only significant pollutant in the four, three, and two pollutant models, its RRs being smaller than that in the single pollutant model.

No significant interaction between any pair of pollutants was found in the pairwise analyses, or between any pollutant and the cold season. None of the coefficients of the interaction terms between the pollution concentration and the mean mortalities of the previous days from lag day 2 up to day 21 were significantly negative, suggesting the absence of a harvesting effect. When RRs of deciles of the pollutant concentrations were derived from each single pollutant model, with the lowest decile as reference, an upward trend in RRs was found for all pollutants from the lowest to the highest deciles (fig 1).

\begin{tabular}{|c|c|c|c|c|}
\hline & $\mathrm{SO}_{2}$ & $\mathrm{O}_{3}$ & $\mathrm{NO}_{2}$ & $\mathrm{PM}_{10}$ \\
\hline $\begin{array}{l}\text { Respiratory diseases } \\
\text { RR } \\
95 \% \mathrm{Cl}\end{array}$ & $\begin{array}{l}\text { Lag } 0-1 \text { days } \\
1.015 \\
(1.001 \text { to } \\
1.029)\end{array}$ & $\begin{array}{l}\text { Lag } 2 \text { days } \\
1.010 \\
(1.004 \text { to } \\
1.016)\end{array}$ & $\begin{array}{l}\text { Lag } 0-1 \text { days } \\
1.013 \\
(1.004 \text { to } \\
1.022)\end{array}$ & $\begin{array}{l}\text { Lag } 1 \text { day } \\
1.008 \\
(1.001 \text { to } \\
1.014)\end{array}$ \\
\hline $\begin{array}{l}\text { Chronic obstructive pulmonary } \\
\text { diseases }\end{array}$ & Lag 2 days & Lag $0-4$ days & Lag $0-2$ days & $\operatorname{Lag} 0-3$ days \\
\hline $\begin{array}{l}\mathrm{RR} \\
95 \% \mathrm{Cl}\end{array}$ & $\begin{array}{l}1.010 \\
(0.990 \text { to } \\
1.029)\end{array}$ & $\begin{array}{l}1.034 \\
(1.017 \text { to } \\
1.052)\end{array}$ & $\begin{array}{l}1.023 \\
(1.006 \text { to } \\
1.041)\end{array}$ & $\begin{array}{l}1.017 \\
(1.002 \text { to } \\
1.033)\end{array}$ \\
\hline $\begin{array}{l}\text { Pneumonia and influenza } \\
\text { RR } \\
95 \% \mathrm{Cl}\end{array}$ & $\begin{array}{l}\text { Lag } 0-1 \text { days } \\
1.021 \\
(1.003 \text { to } \\
1.039)\end{array}$ & $\begin{array}{l}\text { Lag } 2 \text { days } \\
1.007 \\
(0.999 \text { to } \\
1.015)\end{array}$ & $\begin{array}{l}\text { Lag } 0-3 \text { days } \\
1.016 \\
(1.002 \text { to } \\
1.030)\end{array}$ & $\begin{array}{l}\text { Lag } 2 \text { days } \\
1.007 \\
(0.999 \text { to } \\
1.015)\end{array}$ \\
\hline $\begin{array}{l}\text { Cardiovascular diseases } \\
\text { RR } \\
95 \% \mathrm{Cl}\end{array}$ & $\begin{array}{l}\text { Lag } 0-1 \text { days } \\
1.007 \\
(0.994 \text { to } \\
1.020)\end{array}$ & $\begin{array}{l}\text { Lag } 0 \text { day } \\
0.997 \\
(0.991 \text { to } \\
1.003)\end{array}$ & $\begin{array}{l}\text { Lag } 0-2 \text { days } \\
1.008 \\
(0.999 \text { to } \\
1.016)\end{array}$ & $\begin{array}{l}\text { Lag } 2 \text { days } \\
1.003 \\
(0.998 \text { to } \\
1.008)\end{array}$ \\
\hline $\begin{array}{l}\text { Ischaemic heart disease } \\
\text { RR } \\
95 \% \mathrm{Cl}\end{array}$ & $\begin{array}{l}\text { Lag } 1 \text { day } \\
1.028 \\
(1.012 \text { to } \\
1.044)\end{array}$ & $\begin{array}{l}\text { Lag } 3 \text { days } \\
1.009 \\
(1.000 \text { to } \\
1.018)\end{array}$ & $\begin{array}{l}\text { Lag } 1 \text { day } \\
1.024 \\
(1.012 \text { to } \\
1.036)\end{array}$ & $\begin{array}{l}\text { Lag } 0-3 \text { days } \\
1.013 \\
(1.001 \text { to } \\
1.025)\end{array}$ \\
\hline $\begin{array}{l}\text { Cerebrovascular disease } \\
\text { RR } \\
95 \% \mathrm{Cl}\end{array}$ & $\begin{array}{l}\text { Lag } 2 \text { days } \\
0.9881 \\
(0.965 \text { to } \\
1.011)\end{array}$ & $\begin{array}{l}\text { Lag } 0 \text { day } \\
0.999 \\
(0.998 \text { to } \\
1.000)\end{array}$ & $\begin{array}{l}\text { Lag } 1 \text { day } \\
0.996 \\
(0.985 \text { to } \\
1.007)\end{array}$ & $\begin{array}{l}\text { Lag } 2 \text { days } \\
1.007 \\
(0.998 \text { to } \\
1.016)\end{array}$ \\
\hline
\end{tabular}


Table 4 RRs $(95 \% \mathrm{Cls})$ for daily numbers of deaths $/ 10 \mu \mathrm{g} / \mathrm{m}^{3}$ increase in concentration of pollutant in multipollutant models*

\begin{tabular}{|c|c|c|c|c|}
\hline Model & $\mathrm{SO}_{2}$ & $\mathrm{O}_{3}$ & $\mathrm{NO}_{2}$ & $\mathrm{PM}_{10}$ \\
\hline \multicolumn{5}{|c|}{ All respiratory mortalities: } \\
\hline 4 Pollutant model & $\begin{array}{l}1.009 \text { (0.990 to } \\
1.029 \text { ) }\end{array}$ & $\begin{array}{l}1.009 \text { (1.002 to } \\
1.016)\end{array}$ & $\begin{array}{l}1.001(0.991 \text { to } \\
1.020)\end{array}$ & $\begin{array}{l}1.005 \text { (0.992 to } \\
1.010)\end{array}$ \\
\hline 3 Pollutant model & $\begin{array}{l}1.010(0.990 \text { to } \\
1.030)\end{array}$ & $\begin{array}{l}1.009(1.002 \text { to } \\
1.016)\end{array}$ & $\begin{array}{l}1.006(0.993 \text { to } \\
1.019)\end{array}$ & \\
\hline 2 Pollutant model & $\begin{array}{l}1.015(1.001 \text { to } \\
1.031)\end{array}$ & $\begin{array}{l}1.010(1.003 \text { to } \\
1.017)\end{array}$ & & \\
\hline \multicolumn{5}{|c|}{ Mortality from COPD: } \\
\hline 4 Pollutant model & $\begin{array}{l}1.007(0.9848 \text { to } \\
1.0296)\end{array}$ & $\begin{array}{l}1.033(1.0126 \text { to } \\
1.0548)\end{array}$ & $\begin{array}{l}1.014 \text { (0.989 to } \\
1.041)\end{array}$ & $\begin{array}{l}0.991(0.968 \text { to } \\
1.015)\end{array}$ \\
\hline 3 Pollutant model & & $\begin{array}{l}1.032 \text { (1.012 to } \\
1.053)\end{array}$ & $\begin{array}{l}1.016(0.991 \text { to } \\
1.042)\end{array}$ & $\begin{array}{l}0.993(0.970 \text { to } \\
1.016)\end{array}$ \\
\hline 2 Pollutant model* & & $\begin{array}{l}1.029(1.011 \text { to } \\
1.049)\end{array}$ & $\begin{array}{l}1.011(0.992 \text { to } \\
1.031)\end{array}$ & \\
\hline \multicolumn{5}{|c|}{ Mortality from pneumonia and influenza: } \\
\hline 4 Pollutant model & $\begin{array}{l}1.018(0.997 \text { to } \\
1.040)\end{array}$ & $\begin{array}{l}1.006(0.997 \text { to } \\
1.015)\end{array}$ & $\begin{array}{l}1.004(1.017 \text { to } \\
1.025)\end{array}$ & $\begin{array}{l}1.002(0.991 \text { to } \\
1.013)\end{array}$ \\
\hline 3 Pollutant model & $\begin{array}{l}1.017(0.996 \text { to } \\
1.039)\end{array}$ & $\begin{array}{l}1.006(0.997 \text { to } \\
1.016)\end{array}$ & $\begin{array}{l}1.006 \text { (0.989 to } \\
1.024)\end{array}$ & \\
\hline 2 Pollutant model & $\begin{array}{l}1.021 \text { ( } 1.003 \text { to } \\
1.039 \text { ) }\end{array}$ & $\begin{array}{l}1.008 \text { (0.999 to } \\
1.016)\end{array}$ & & \\
\hline \multicolumn{5}{|c|}{ Mortality from ischaemic heart diseases: } \\
\hline 4 Pollutant model & $\begin{array}{l}1.011(0.990 \text { to } \\
1.033)\end{array}$ & $\begin{array}{l}1.007 \text { (0.998 to } \\
1.017)\end{array}$ & $\begin{array}{l}1.020 \text { (1.003 to } \\
1.035)\end{array}$ & $\begin{array}{l}0.9940 \text { (0.978 to } \\
1.009)\end{array}$ \\
\hline 3 Pollutant model & $\begin{array}{l}1.012(0.991 \text { to } \\
1.033)\end{array}$ & $\begin{array}{l}1.006(0.998 \text { to } \\
1.015)\end{array}$ & $\begin{array}{l}1.016(1.002 \text { to } \\
1.032)\end{array}$ & \\
\hline 2 Pollutant model & & $\begin{array}{l}1.006 \text { (0.997 to } \\
1.014)\end{array}$ & $\begin{array}{l}1.022(1.011 \text { to } \\
1.003)\end{array}$ & \\
\hline
\end{tabular}

\section{DISCUSSION}

This study provides additional information for our previous study on hospital admissions, ${ }^{21}$ and the many time series studies on air pollution and mortality in temperate countries. ${ }^{1-11} 1315$ 17-19 $282933-353839$ Although hospital admissions are influenced by socioeconomic and personal factors, mortality is the ultimate and most serious of all health outcomes. As explained earlier, both the mortality and air pollutant datasets were of reasonable quality. Our statistical methods followed the APHEA protocol, which facilitated the comparison of results. Significant associations were found with respiratory mortalities for all four pollutants in the single pollutant models. For the different respiratory diseases, the best lags ranged from 1 to 2 single lag days and 0 to 4 cumulative lag days. These lag periods were statistically chosen by model fitness. The durations of the lag periods, however, seemed reasonable, if we assume a short interval (in terms of
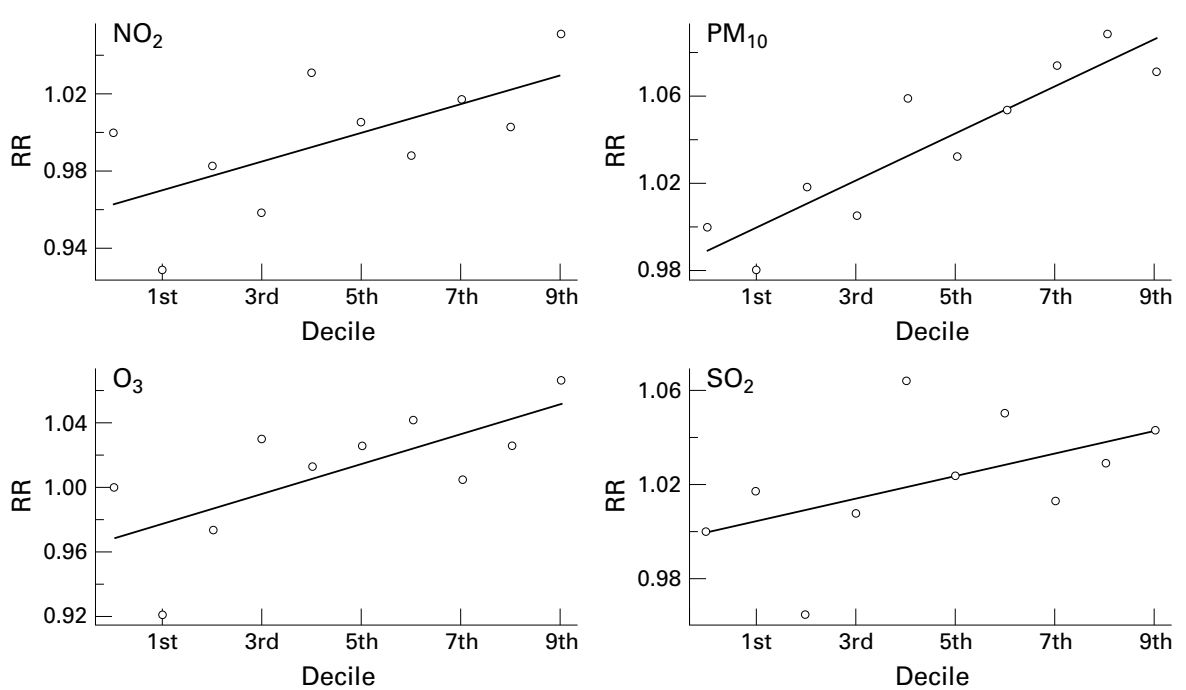

several days) between exposure and death, which varies with different diseases. It is also reasonable to assume that mortality might be associated with cumulative exposure over several days. The risk estimates for respiratory mortalities, at $0.8 \%$ to $1.5 \%$ per $10 \mu \mathrm{g} / \mathrm{m}^{3}$ increase in pollutant concentration were similar in magnitude to results reported elsewhere. ${ }^{30}$ These mortality risks were, however, lower than risks of hospital admissions we reported previously ( $1.3 \%$ to $2.2 \%$ per $10 \mu \mathrm{g} / \mathrm{m}^{3}$ increase). ${ }^{21}$ Of the respiratory diseases, the RRs for mortalities from COPD, the most sensitive mortality to air pollution, were higher for $\mathrm{O}_{3}$ and $\mathrm{NO}_{2}$ (at increases of 3.4\% and $2.3 \%$ respectively). The RRs of cardiovascular mortalities were non-significant for all four pollutants, by contrast with our previous findings for hospital admissions for cardiovascular diseases. ${ }^{21}$ Mortalities for IHD were significantly associated with all four pollutants, suggesting that the associations of air pollution were disease specific. Of cardiovascular diseases, the RRs of deaths from IHD (at 1.028 and 1.024 respectively) were

Figure 1 A regression line is fitted to show the upward trend of the RRs. RRs were derived from the Poisson regression models in which the concentrations of the individual pollutants were replaced by their respective deciles. See statistical analysis in the methods section. 
the highest for $\mathrm{NO}_{2}$ and $\mathrm{SO}_{2}$. However, a direct comparison of the magnitude of the RRs among the air pollutants can be misleading, because of differences in molecular weight. By contrast with our findings, a pooled analysis among European countries showed equivocal RRs of cardiovascular and respiratory deaths for $\mathrm{NO}_{2}$ but significant RRs for black smoke, $\mathrm{SO}_{2}$, and $\mathrm{O}_{3}{ }^{29}$ The summary $\mathrm{RRs}$ for $\mathrm{SO}_{2}$ and $\mathrm{O}_{3}$ in western European cities are similar in magnitude to ours. In Hong Kong, the mean concentrations of $\mathrm{O}_{3}, \mathrm{NO}_{2}$, and $\mathrm{PM}_{10}$ are generally higher, but the concentrations of $\mathrm{SO}_{2}$ are much lower than in European cities. Our findings of a significant RR of IHD for $\mathrm{SO}_{2}$ suggest that the threshold has not been reached at the current $\mathrm{SO}_{2}$ concentrations.

Owing to the high correlation between pollutants, it is not clear whether the observed effect of one pollutant in the single pollutant model represents that of an underlying pollutant. Much research focus has been given to the respirable fraction of particulates, and more recently, fine particulates $\left(\mathrm{PM}_{2.5}\right){ }^{31}{ }^{32}$ In the multipollutant model for both respiratory diseases and IHD, no significant effect for PM $_{10}$ could be discerned. It should be noted that in some studies in the United States and Europe where the effects of particulates were significant, single pollutant models were used. $.^{2-6} 12-151729$ These results agreed with that of our single pollutant model for $\mathrm{PM}_{10}$. Our findings of significant associations of $\mathrm{SO}_{2}$ and $\mathrm{O}_{3}$ with respiratory deaths are in accord with those in many European cities and elsewhere. ${ }^{45812151733-36}$ The problems of collinearity among pollutants in a multipollutant model are well recognised. In our data, the concentrations of $\mathrm{NO}_{2}$ and $\mathrm{PM}_{10}$ were highly correlated on the same days (table 2), and on the best lag days that were used in the multipollutant model $(r=0.73)$. The correlation between all the other pairs of pollutants ranged from trivial to moderate (Pearson's $r$ ranged from -0.07 to 0.45 for the best lag days). Hence, it is statistically valid to include $\mathrm{SO}_{2}, \mathrm{O}_{3}$, and either of $\mathrm{NO}_{2}$ and $\mathrm{PM}_{10}$ in the models. For all respiratory mortalities and COPD, the RR for $\mathrm{O}_{3}$ was remarkably stable in all the models. A significant association with $\mathrm{O}_{3}$ for respiratory mortality in our multipollutant model is biologically plausible. Firstly, $\mathrm{O}_{3}$ is a highly toxic oxidant pollutant with known adverse effects on the respiratory system. ${ }^{37}$ Secondly, the concentration of $\mathrm{O}_{3}$ in Hong Kong is higher than in many cities in Europe and the United States, possibly related to the abundance of sunshine, even in winter months. In our earlier study on hospital admissions, $\mathrm{O}_{3}$ was significantly associated with admissions for both respiratory and cardiovascular diseases. ${ }^{21}$

The high ambient concentration of $\mathrm{NO}_{2}$ in Hong Kong is a possible explanation of our finding of a significant association with mortalities from IHD. Significant associations between $\mathrm{NO}_{2}$ and all cardiovascular mortalities have been reported in some studies. ${ }^{410}{ }^{13}$ However, the relations between $\mathrm{NO}_{2}$ and cardiovascular mortalities were inconsistent in a metaanalysis of pooled data from four European cities. ${ }^{29}$ The reasons for the lack of association of $\mathrm{PM}_{10}$ with any respiratory or cardiovascular mortalities in a multipollutant model are not clear. The effects of $\mathrm{PM}_{10}$ might have been masked by those of $\mathrm{NO}_{2}$ and $\mathrm{O}_{3}$ - the concentrations of both were fairly high. Neither could we explain why $\mathrm{SO}_{2}$, rather than $\mathrm{PM}_{10}$, was associated with deaths from pneumonia and influenza, especially when the mean concentration of $\mathrm{SO}_{2}$ was relatively low and that of $\mathrm{PM}_{10}$ was fairly high. The chemical composition of particulates might be related to the effects on health. In Hong Kong, diesel vehicle exhaust is a major source of $\mathrm{PM}_{10^{\prime}}$ although crustal dust and marine aerosols are important sources as well. ${ }^{20}$

No interaction was detected in this study between any two pollutants, whether analysed in pairs or when all four pollutants were considered together. Significant interactions between particulates and $\mathrm{SO}_{2}$ have been reported in Athens and Lyon in the APHEA mortality studies. ${ }^{15} 33$ The discrepancies might be due to differences in concentrations of pollutant

\section{Key messages}

- Significantly increased risks of mortality from all respiratory diseases and ischaemic heart diseases were shown at current ambient concentrations of particulates, sulphur dioxide, nitrogen dioxide, and ozone.

- The associations between mortality and particulates and some gaseous pollutants concurred with many studies in temperate countries.

- The associations were not explained by "harvesting" of vulnerable populations and the effect of air pollution was likely to be real.

- A dose-response relation between the relative risks and the concentrations of the pollutants was found for all four air pollutants.

- When all pollutants were included in the models, ozone and sulphur dioxide remained significantly associated with respiratory mortalities, whereas nitrogen dioxide was associated with mortality from ischaemic heart disease.

\section{Policy implications}

- Current air quality standards are not sufficient to protect the public from adverse health effects.

- Further control of air pollution is likely to result in health benefits.

between Hong Kong and these cities. The absence of interaction with the cold season could be related to the relatively mild winters in Hong Kong, where the mean monthly temperatures from December to February ranged from $15^{\circ}$ to $19^{\circ} \mathrm{C}$ and the mean daily temperature rarely drops below $10^{\circ} \mathrm{C}$. When analyzed by deciles of pollutant concentrations, a doseresponse relation was found for all pollutants and respiratory mortalities, with no evidence of a threshold effect.

The role of $\mathrm{CO}$ on cardiovascular mortalities has been investigated elsewhere. Touloumi et al reported a positive association between ambient $\mathrm{CO}$ concentrations and daily mortality in Athens, ${ }^{38}$ but this association was reduced considerably after including $\mathrm{CO}$ and black smoke or $\mathrm{SO}_{2}$ in the same model. Carbon monoxide was not considered as a copollutant in other time series analyses. ${ }^{39}$ Owing to the insufficiency of data, we did not evaluate the effect of $\mathrm{CO}$, which might be relevant to cardiovascular mortalities. The ambient concentration of $\mathrm{CO}$ in Hong Kong is low. The mean 24 hour concentration was 800 $\mu \mathrm{g} / \mathrm{m}^{3}$, less than one tenth of the local air quality objective of $10000 \mu \mathrm{g} / \mathrm{m}^{3} .^{20}$

The absence of a harvesting effect of respiratory and cardiovascular mortalities within a 3 week period suggests that the shortening of life is likely to be substantial. Schwartz suggested that deaths from chronic obstructive airway diseases were mostly brought forward by a few months, whereas some (but not most) deaths from pneumonia might be brought forward by a few days. ${ }^{40}$ We have not investigated the harvesting effect of specific causes of death on different time scales.

In conclusion, we found significant associations of all four air pollutants with mortalities from respiratory disease and IHD, the effect size being strongest for COPD. Although the multipollutant model selected $\mathrm{SO}_{2}$ and $\mathrm{O}_{3}$ as significant pollutants for respiratory deaths and $\mathrm{NO}_{2}$ for deaths from ischaemic heart disease, other pollutants such as $\mathrm{PM}_{10}$ might play an important part. The joint effects of the air pollutants are still poorly understood and comparative studies in cities with different pollutant profiles are warranted. The ecological design of the study precludes the inference of cause and effect. 
As the current ambient concentrations of these pollutants seem to be above the threshold, some health benefits should be noticeable if air pollution is reduced. A reduction in morbidity and mortality after the implementation of an intervention programme will add evidence to the hypothesis of a causal link between air pollution and ill health.

\section{Authors' affiliations}

T W Wong, W S Tam, T S Yu, A H S Wong, Department of Community and Family Medicine, The Chinese University of Hong Kong, 4/F School of Public Health, Prince of Wales Hospital, Shatin, N T, Hong Kong

\section{REFERENCES}

1 Schwartz J. Particulate air pollution and daily mortality in Detroit. Environ Res 1991:56:204-13.

2 Schwartz J, Dockery D. Particulate air pollution and daily mortality in Steubenville, Ohio. Am J Epidemiol 1992;135:12-19.

3 Schwartz J. Air pollution and daily mortality in Birmingham, Alabama. Am J Epidemiol 1993;137:1 136-47.

4 Anderson R, Ponce de Leon A, Bland J, et al. Air pollution and daily mortality in London, 1987-92. BM 1996;312:665-9.

5 Kelsall JE, Samet JM, Zeger SL, et al. Air pollution and mortality in Philadelphia, 1974-88. Am J Epidemiol 1997;146:750-62.

6 Wordley J, Walters S, Ayres JG. Short term variations in hospital admissions and mortality and particulate air pollution. Occup Environ Med 1997;54:108-16.

7 Hong YC, Leem JH, Ha EH, et al. PM 10 exposure, gaseous pollutants, and daily mortality in Inchon, South Korea. Environ Health Perspect 1999; 107:873-8.

8 Morgan G, Corbett S, Wlodarczyk J, et al. Air pollution and daily mortality in Sydney, Australia, 1989 through 1993. Am J Public Health 1998;88:759-64.

9 Peters A, Skorkovsky J, Kotesovec F, et al. Associations between mortality and air pollution in Central Europe. Environ Health Perspect 2000;108:283-87.

10 Mar TF, Norris GA, Loenig JQ, et al. Associations between air pollution and mortality in Phoenix, 1995-1997. Environ Health Perspect 2000; 108:347-53

11 Hales S, Salmond G, Town Gl, et al. Daily mortality in relation to weather and air pollution in Christchurch, New Zealand. Aust N Z Public Health 1999;24:89-91.

12 Simpson RW, Williams G, Petroeschersky A, et al. Associations between outdoor air pollution and daily mortality in Brisbane, Australia. Arch Environ Health 1997:52:442-54.

13 Bremmer SA, Anderson HR, Atkinson RW, et al. Short term association between outdoor air pollution and mortality in London 1992-4. Occup Environ Med 1999;56:237-44.

14 Gouvea N, Fletcher T. Time series analysis of air pollution and mortality: effects by cause, age and socioeconomic status. J Epidemiol Community Health 2000:54:750-5.

15 Touloumi G, Samoli E, Katsouyanni K. Daily mortality and "winter type" air pollution in Athens, Greece: a time series analysis within the APHEA project. J Epidemiol Community Health 1996;50(suppl 1):S47-51.

16 Kunst AE, Looman CWN, Mackenbach JP. Outdoor air temperature and mortality in the Netherlands: a time-series analysis. Am J Epidemiol $1993 ; 137: 331-41$
17 Sunyer J, Castellsague J, Saez $M$, et al. Air pollution and mortality in Barcelona. J Epidemiol Community Health 1996;50(suppl 1):S76-80.

18 Xu X, Dockery DW, Gao J, et al. Air pollution and daily mortality in residential areas of Beijing, China. Arch Environ Health 1994:49:216-22.

19 Lee JT, Shin D, Chung Y. Air pollution and daily mortality in Seoul and Ulsan, Korea. Environ Health Perspect 1999; 107: 149-54.

20 Environmental Protection Department. Air quality in Hong Kong 1998. Hong Kong: Hong Kong Government, 1999:3-13.

21 Wong TW, Lau TS, Yu TS, et al. Air pollution and hospital admissions for respiratory and cardiovascular diseases in Hong Kong. Occup Environ Med 1999;56:679-83

22 Katsouyanni K, Schwartz J, Spix C, et al. Short term effects of air pollution on health: a European approach using epidemiologic time series data: the APHEA protocol. J Epidemiol Community Health 1996;50(suppl 1):S12-18.

23 Schwartz J, Spix C, Touloumi G, et al. Methodological issues in studies of air pollution and daily counts of deaths or hospital admissions. J Epidemiol Community Health 1996;50(suppl 1):S3-11.

24 McCullagh P, Nelder JA. Generalized linear models. London: Chapman and Hall, 1989:323-32.

25 SAS Institute. SAS/STAT Software: The GENMOD Procedure, Release 6.09, Cary, NC: SAS Institute, 1993. (SAS Technical Report P-243.)

26 Box GP, Jenkins GM, Reinsel GC. Time series analysis: forecasting and control. Englewood Cliffs, NJ, Prentice-Hall International, 1994:21-45.

27 Akaike H. Factor analysis and AIC. Psychometrika 1987. 52:317-32.

28 Spix C, Heinrich J, Dockery D, et al. Air pollution and daily mortality in Erfurt, East Germany, 1980-9. Environ Health Perspect 1993;101:518-26

29 Zmirou D, Schwartz J, Saez M, et al. Time-series analysis of air pollution and cause-specific mortality. Epidemiology 1998;9:495-503.

30 Pope CA III, Bates DV, Raizenne ME. Health effects of particulate air pollution: time for reassessment? . Environ Health Perspect $1995 ; 103: 472-580$

31 Boria-Aburto VH, Castillejos M, Gold DR, et al. Mortality and ambient fine particles in southwest Mexico City, 1993-5. Environ Health Perspect 1998; 106:849-55.

32 Norris G, YoungPong SN, Koenig JQ, et al. An association between fine particles and asthma emergency department visits for children in Seattle. Environ Health Perspect 1999:107:489-93.

33 Zmirou D, Barumandzadeh T, Balducci F, et al. Short term effects of air pollution on mortality in the city of Lyon, France, 1985-90. J Epidemiol Community Health 1996;50:S30-5

34 Spix C, Wichmann HE. Daily mortality and air pollutants: findings from Koln, Germany. J Epidemiol Community Health 1996:50:S52-8.

35 Vigotti MA, Rossi G, Bisanti L, et al. Short term effects of urban air pollution on respiratory health in Milan, Italy, 1980-9. J Epidemiol Community Health 1996;50:S71-5.

36 Saldiva P, Lichtenfels A, Paiva PS, et al. Association between air pollution and mortality due to respiratory diseases in children in Sao Paulo, Brazil: a preliminary report. Environ Res 1994;65:218-25.

37 Committee of the Environmental and Occupational Health Assembly of the American Thoracic Society. Health effects of outdoor air pollution. Am J Crit Care Med 1996;153:3-50.

38 Touloumi G, Pocock SJ, Katsouyanni K, et al. Short-term effects of air pollution on daily mortality in Athens: a time series analysis. Int $J$ Epidemiol 1994;23:957-67.

39 Verhoeff AP, Hoek G, Schwartz J, et al. Air pollution and daily mortality in Amsterdam. Epidemiology 1996;7:225-30.

40 Schwartz J. Harvesting and long term exposure effects in the relation between air pollution and mortality. Am J Epidemiol 2000;151:440-8. 


\section{LETTERS}

\section{Neurobehavioural testing in workers occupationally exposed to lead}

Whether or not low to modest levels of exposure to lead have a detrimental effect on cognition is an important issue given the growing attention, for example, in the United States, that has recently been paid towards potentially revising downward the levels of lead exposure allowed in the workplace. Thus, we read with interest the meta-analysis of studies on this topic that appeared in this journal by Goodman and colleagues. ${ }^{1}$ Unfortunately, we believe that the authors' conclusions are not valid. Specifically, the authors state that "the data available to date are inconsistent and are unable to provide adequate information on the neurobehavioural effects of exposure to moderate blood concentrations of lead". We found no direct support for this conclusion in the publication. Moreover, numerous flaws in their method limit any specific inferences that can be made. In general, we found that the meta-analysis combined evidence from studies of widely varying quality and did not account for significant confounding within and between studies. Given these and othe flaws, it was predictable that the authors did not find an association between blood lead levels and neurobehavioural test scores.

Specific concerns that we had with the methods include: (1) The authors offer no evaluation of the quality of the evidence from available studies based on study design and analytical method. (2) The authors combine data from poorly done studies with data from well done studies, clouding any effects that are observable from the better conducted studies. (3) Although age and education adjustment within studies is assessed, six studies were included that did not adjust for age, and another three studies did not adjust for education. These are the two most well established predictors of neurobehavioural test scores and the most important potentially confounding variables. (4) Even among the remaining studies that did adjust for age and education, the authors do not address the confounding in the meta-analysis that is caused by variation in age and education across study populations. (5) The authors' main effect measure is an exposed versus control comparison. Among the options that could have been pursued, this is the effect measure with the lowest power. It is unable to assess a dose-effect relation, and it is also the one most prone to selection bias. (6) Relatively few of the 22 studies listed in table 2 contribute to the estimate of the effect size for each neurobehavioural outcome. Moreover, the authors do not state which studies contributed to the effect estimate.

It is important to note that several recent studies, all published before this article was accepted for publication, reported that blood lead was associated with neurobehavioural test scores in multiple cognitive domains. One study of 803 Korean lead workers is the largest study reported to date and observed consistent associations of blood lead with tes scores in the domains of executive abilities,
If you have a burning desire to respond to a paper published in Occupational and Environmental Medicine, why not make use of our "rapid response" option?

Log on to our website (www.occenvmed.com), find the paper that interests you, and send your response via email by clicking on the "eletters" option in the box at the top right hand corner.

Providing it isn't libellous or obscene, it will be posted within seven days. You can retrieve it by clicking on "read eletters" on our homepage.

The editors will decide as before whether to also publish it in a future paper issue.

manual dexterity, and peripheral motor strength at blood lead levels as low as 18 $\mathrm{\mu g} / \mathrm{dl}{ }^{2}$ In another study of former organolead manufacturing workers, tibia lead was associated with test scores at cross section and with longitudinal declines in test scores. ${ }^{3}$ These findings suggest that lead may have both short term and progressive influences on neurobehavioural performance.

We elaborate on our main concerns, below.

(1) No evaluation of the quality of the evidence available from studies, and (2) Data from poorly done studies were combined with data from well done studies. It is traditional in meta-analysis to establish a priori criteria for what defines acceptable evidence from studies. The authors only had three inclusion criteria, none of which refer to the quality of the study designs, analytical method, adjustment for confounding, evaluation of bias in selection of exposed and non-exposed subjects, and other such methodological factors. There is apparently no consideration for this arguably single most important step in metaanalysis. The meta-analytical results could simply reflect wide heterogeneity in the quality of the evidence that was combined. This factor alone could account for the overall conclusion of no association.

(3) Inclusion of studies that did not control for age and education. Age and education are the two most important predictors of neurobehavioural test scores in working populations. In the absence of adjustment for these confounders there should be convincing evidence that the two groups being compared were equivalent in age and education. Eight of the included studies did not adjust for age and/or education. The authors offer no explanation for why these studies should be included in the meta-analysis.

(4) No adjustment for age, education, or lead dose differences across studies. By not adjusting for age and education differences across studies, the authors make an implicit assumption that age and education do not modify the relation between blood lead and neurobehavioural test scores. This may or may not be true. In the meta-analysis, the authors also implicitly assume a fixed difference in blood lead levels between exposed and nonexposed groups. Table 1 clearly indicates that this assumption does not hold

(5) Reliance on exposed versus control comparisons. This is a weak test and a test that is not germane to the conclusions that the authors make. The authors conclude that blood lead levels, that are described as "moderate" in one location in the manuscript and "low" in another, are not associated with neurobehavioural test scores. All studies included exposed workers with a range of blood lead levels, from very low to high. More appropriate approaches could have been considered, for example, only including studies that reported beta coefficients for the blood lead versus test score relation, or adjusting for mean blood lead levels in exposed and non-exposed groups.

(6) Reliance on a small number of unspecified studies for effect estimates. Table 2 of the meta-analysis reports the number of studies that were combined to derive effect estimates, but does not specify which studies were combined. This omission does not allow the reader to determine whether solid evidence was combined with more questionable evidence, or to evaluate whether any of the issues described above were germane to the effect estimates reported.

Two more concerns exist regarding the authors' treatment of the issue of cumulative versus ongoing lead exposure, as well as the identification of the source of funding for this study. In their introduction, the authors quote the review by Balbus-Kornfeld et al, which noted that "the current scientific evidence is flawed because of inadequate estimation of cumulative exposure to or absorption of lead

"." but fail to acknowledge this issue in the interpretation of their own meta-analysis. In fact, as has been widely reported in the literature, methods are now available to noninvasively measure bone lead levels as a reliable and accurate measure of cumulative lead dose. Several studies ${ }^{3-5}$ suggest that cumulative lead dose, as measured by tibia lead levels, is a very important biological marker that may be related to cognitive decrements not predicted by blood lead levels. With regard to funding, the authors note that they are mainly from the Exponent Health Group in Alexandria, Virginia, and Menlo Park, California; however, they fail to describe what motivated the study or sources of funding for the study. We believe this information would be of interest to scientists and policy makers engaged in work on this topic.

B S Schwartz

Professor and Director, Division of Occupational and Environmental Health, Johns Hopkins Bloomberg School of Public Health: bschwart@jhsph.edu

W Stewart

Adjunct Professor, Department of Epidemiology, Johns Hopkins Bloomberg School of Public Health

$\mathrm{H} \mathrm{Hu}$ Associate Professor and Director Occupational/Environmental Medicine, Department of Environmental Health, Harvard School of

Public Health

\section{References}

1 Goodman M, LaVerda N, Clarke C, et al. Neurobehavioural testing in workers occupationally exposed to lead: systematic review and meta-analysis of publications. Occup Environ Med 2002;59:217-23. 
2 Schwartz BS, Lee BK, Lee GS, et al. Associations of blood lead, dimercaptosuccinic acid-chelatable lead, and tibia lead with neurobehavioral test scores in South Korean lead workers. Am J Epidemiol 2001;153:453-64.

3 Stewart WF, Schwartz BS, Simon D, et al. Neurobehavioral function and tibial and chelatable lead levels in 543 former organolead workers. Neurology 1999;52:1610-17

4 Schwartz BS, Stewart WF, Bolla KI, et al. Past adult lead exposure is associated with longitudinal decline in cognitive function. Neurology 2000;55: 1 144-50.

5 Payton M, Riggs KM, Spiro A III, et al. Relations of bone and blood lead to cognitive function: the VA Normative Aging Study. Neurotox Teratol 1998;20:19-27.

\section{Suicide mortality among electricians}

Järvholm and Stenberg ${ }^{1}$ evaluated suicide mortality rates among electricians ("exposed to electromagnetic fields (EMFs)") and glass and wood workers ("unexposed to EMFs") in the Swedish construction industry. Standard mortality rates were lower for the two job groups compared to the Swedish general population. This is likely to be due to the healthy worker effect. The internal cohort analysis showed that electricians had a lower suicide mortality rate than glass and wood workers.

As the authors rightfully point out, these results should not be seen as evidence against the association between exposure to EMFs and suicide, in particular because no quantita tive estimates of exposure were obtained to directly evaluate this association. Järvholm and Stenberg cited a small measurement sur vey in the Swedish construction industry, which indicated that exposure levels were low and comparable between the two occupational groups. Therefore, one would not expect to see an EMF mediated increase in suicide risk among electricians compared to glass and wood workers, if an association between EMF exposure and suicide truly exists.

Järvholm and Stenberg suggested that the difference in suicide rate between the two job groups was unlikely to be due to differences in socioeconomic factors, but they did not provide an alternative explanation. One possible explanation may be a healthy worker survivor effect related to employment status (for example, at time of death) within this cohort That is, active workers may be more physically and mentally fit than those who left the industry or are unemployed, and may therefore be at lower risk of committing suicide. ${ }^{2} \mathrm{~A}$ large body of literature suggests that unemployment and suicide are positively related, ${ }^{3}$ and being out of work was positively associated with suicide in the electric utility industry. ${ }^{2}$ Since cessation of work also leads to cessation of work related exposures, employment status may be an important potential confounder (or perhaps effect modifier) for the association between work related exposures and suicide. The lower suicide rate among electricians compared to glass and wood workers may be explained by a larger proportion of glass and wood workers with an inactive employment status at the time of death.

Although it is unlikely that consideration of employment status, if possible, would greatly alter the conclusions reached by Järvholm and Stenberg, ${ }^{1}$ it would be informative to see its influence on the rate ratio.

E van Wijngaarden Department of Epidemiology, School of Public Health, University of North Carolina at Chapel Hill, Chapel Hill, NC 27599-7435, USA edwin@unc.edu

\section{References}

1 Jarvholm B, Stenberg A. Suicide mortality among electricians in the Swedish construction industry. Occup Environ Med 2002; 59: 199-200.

2 van Wijngaarden E, Savitz DA, Kleckner RC, et al. Exposure to electromagnetic fields and suicide among electric utility workers: a nested case-control study. Occup Environ Med 2000;57:258-63.

3 Dooley D, Fielding J, Levi L. Health and unemployment. Annu Rev Public Health 1996;17:449-65

4 Kposowa AJ. Suicide mortality in the United States: differentials by industrial and occupational groups. Am J Ind Med 1999;36:645-52

\section{Authors' reply}

We appreciate Dr Wijngaarden's interest in our report and his suggestion for understanding the differences in risk. Dr Wijngaarden suggests that difference in unemployment rate between electricians and glass worker and wood workers could be an explanation.

We have no data on employment status at time of death and can therefore not test this hypothesis. However, if employment status is an important predictor, this could explain some of the difference, as the wood workers had a different employment structure to the other groups. Electricians and glass workers have had permanent positions for a long time, while wood workers were employed for a certain project, for example, building a house, before the 1990s. When the project was finished they had to find another employer. Today, most construction workers have permanent positions in Sweden.

In our search of the literature in an attemp to understand differences in suicide rates between occupations, we found little information. This might be an important area of research in the future.

B Jarvholm, A Stenberg

Dept of Public Health and Clinical Medicine Occupational Medicine, Umeå University, S-901 87 Umeå, Sweden bengt.jarvholm@envmed.umu.se

\section{Are incinerator workers exposed to PCDDs and PCDFs?}

Kumagai and his colleagues ${ }^{1}$ have reported that incinerator workers employed at intermittently burning incineration plants were not necessarily exposed to high concentrations of polychlorinated dibenzo- $p$-dioxins (PCDDs) and polychlorinated dibenzofurans (PCDFs). The authors' conclusions were based on concentrations of PCDDs and PCDFs in serum samples of the workers.

I have deep concerns regarding the study methodology and results which do not consider the accumulation of PCDDs and PCDFs in the adipose tissue. PCDDs and PCDFs are organochlorines with different degrees and positions of chlorination, which determine their persistence and toxicity. They are lipophilic and difficult to metabolise, and any environmental exposure of living organisms to them results in their accumulation and persistence in fat tissues. ${ }^{2}$ Meanwhile, it is feasible to use blood sera to obtain and analyse PCDDs and PCDFs. Adipose tissue organochlorines levels have been regarded as a preferred indicator of human exposure. Levels in adipose tissue are known to be higher and more representative of the cumulative internal exposure. ${ }^{23}$ Previously, ArchibequeEngle and colleagues ${ }^{4}$ did not find a significant relation between serum concentration and tissue residues for organochlorine compounds. Based on the lack of correlation between adipose tissue and serum, as well as an absence of some compound residues in serum, the authors emphasised that adipose tissue should be analysed in addition to serum

Finally, I would like to acknowledge the authors for such original subject study, which enables us to raise the profile of and discuss new hypotheses in environmental and occupational health.

Department of Preventive Medicine and Public Health, University of Cordoba, Spain:

fm2faahm@uco.es

\section{References}

1 Kumagai S, Koda S, Miyakita T, et al. Polychlorinated dibenzo-p-dioxin and dibenzofuran concentrations in serum samples of workers at intermittently burning municipal waste incinerators in Japan. Occup Environ Med 2002;59:362-8.

2 Angulo R, Martinez P, Jodral ML. PCB congeners transferred by human milk, with an estimate of their daily intake. Food Chem Toxicol 1999;37:1 1081-8

3 Lopez-Carrillo L, Torres-Sanchez L, Lopez-Cervantes $M$, et al. The adipose tissue to serum dichlorodiphenyldichloroethane (DDE) ratio: some methodological considerations. Environ Res 1999;81:142-5.

4 Archibeque-Engle SL, Tessari JD, Winn DT, et al. Comparison of organochlorine pesticide and polychlorinated biphenyl residues in human breast adipose tissue and serum. J Toxicol Environ Health 1997;52:285-93.

\section{Importance of work intensity on respiratory problems in hairdressers}

We read the report by Hollund et al with great interest. ${ }^{1}$ We agree that there is limited information about the prevalence of airway symptoms caused by highly reactive chemicals in hairdressing salons. In this well designed study, authors focused on age as a risk factor and observed an increased prevalence of respiratory symptoms among the oldest and youngest hairdressers and observed more symptoms among hairdressers over 40 years of age.

Work intensity, work duration, working conditions, and job titles (master, and fellow hairdresser) should also be considered as risk factors for occupational asthma and respiratory symptoms. With the exception of work intensity, these features have been reported as risk factors in previous studies. ${ }^{2-4}$ Work intensity is an objective parameter for evaluating occupational exposures. In our study, we calculated work intensity from the average number of chemical applications per week (bleaching, dye, and permanent wave) and observed a 3.6 times higher risk of occupational asthma among hairdressers with high work intensity (95\% CI 1.2 to 10.9 ) with a significant trend $\left(\chi_{\text {trend }}^{2} 4.9, \mathrm{p}=0.027\right) .{ }^{5}$ However, we did not observe any excess by work duration, which probably is a result of the healthy worker effect. Hollund et al stated that the older hairdressers had more customers than the younger ones, which may be 
evidence of higher occupational exposures. If they had used work intensity as a more objective criterion than age, they might have prevented possible misclassifications by age. Working conditions of hairdressers and exposures depend on country and regional variability, which might also affect study results. In the United States and United Kingdom, the term "hairdressers" is inclusive, denoting women's hairdressers and barbers for men. ${ }^{6}$ In Turkey, however, the term addresses women's hair salons only. Most of the studies on hairdressers have been published from Nordic and industrialised countries. ${ }^{7-11}$ Studies from developing countries will help to describe the extent of occupational health problems among hairdressers and to identify aetiological factors.

M Akpinar-Elci, O C Elci

National Institute for Occupational Safety and Health, DRDS/FSB MS2800 1095 Willowdale Road, Morgantown, WV 26505, USA; mra8@cdc.gov

\section{References}

1 Hollund $\mathrm{BE}$, Moen $\mathrm{BE}$, Lygre $\mathrm{SH}$, et al. Prevalence of airway symptoms among hairdressers in Bergen, Norway. Occup Environ Med 2001:58:780-5.

2 Blainey AD, Ollier S, Cundell D, et al. Occupational asthma in a hairdressing salon. Thorax 1986;41:42-50.

3 Parra FM, Igea JM, Quirce S, et al. Occupational asthma in a hairdresser caused by persulphate salts. Allergy 1992:47:656-60.

4 Schwaiblmair M, Vogelmeier C, Fruhmann $G$. Occupational asthma in hairdressers: results of inhalation tests with bleaching powder. Int Arch Occup Environ Health 1997.70:419-23.

5 Akpinar-Elci $\mathbf{M}$, Cimrin AH, Elci OC Prevalence and risk factors of occupational asthma among hairdressers in Turkey. J Occup Environ Med 2002. In press.

6 Occupational exposures of hairdressers and barbers and personal use of hair colorants; some hair dyes, cosmetic colorants, industrial dyestuffs and aromatic amines. IARC monographs on evaluation of carcinogenic risks to human 1993;57:43-66.

7 Leino T, Tammilehto L, Luukkonen R, et al. Self-reported respiratory symptoms and diseases among hairdressers. Occup Environ Med 1997:54:452-5.

8 Leino T, Tammilehto L, Paakkulainen $\mathrm{H}$, et al. Occurrence of asthma and chronic bronchitis among female hairdressers. A questionnaire study. J Occup Environ Med 1997;39:534-9.

9 Leino T, Tammilehto L, Hytonen M et al. Occupational skin and respiratory diseases among hairdressers. Scand J Work Environ Health 1998;24:398-406.
10 Leino $\mathrm{T}$, Tuomi $\mathrm{K}$, Paakkulainen $\mathrm{H}$, et al. Health reasons for leaving the profession as determined among Finnish hairdressers in 1980-1995. Int Arch Occup Environ Health 1999;72:56-9.

11 Hollund BE, Moen BE. Chemical exposure in hairdresser salons: effect of local exhaust ventilation. Ann Occup Hyg

1998:42:277-82

\section{NOTICES}

27th International Congress on

Occupational Health: The

Challenge of Equity in Safety

and Health at Work, Iguassu

Falls, Brazil, 23-28 February

\section{3}

The Congress will have about nine keynote conferences, approaching different angles of the Central Theme; those themes will then be discussed in depth by Panels (60), where different opinions will be debated. There will be about 60 mini-symposia organised by the $\mathrm{ICOH}$ Scientific Committees and Work Groups; facilities for the presentation of 1000 posters; and about 500 free papers. Interest groups may schedule meetings in Congress areas.

Conference Secretariat

Tel/Fax: (5541) 3536719

Email: icoh2003@com.br

Website: www.icoh2003.com.br

\section{First World Congress on}

Work-Related and

Environmental Allergy (1st

WOREAL), and Fourth

International Symposium on

Irritant Contact Dermatitis (ICD), Helsinki, Finland, 9-12 July

2003

Congress on Work-Related and

Environmental Allergy

- Work related and environmental aspects of respiratory and skin allergy

- Specific issues related to pathophysiology and skin allergy
- Management and prevention of allergy Irritant Contact Dermatitis Symposium

- Occupational irritant dermatitis

- Prevention of irritant dermatitis

- Alternative methods for the assessment of irritants

- Irritant dermatitis from cosmetics

Satellite events

- Satellite Symposia, 9 July 2003

- Allergy School, 9-10 July 2003

- 7th International NIVA Course on WorkRelated Respiratory Hypersensitivity, 11-15 July 2003

Congress Secretariat

Ms Kirsi Saarelma, Congress Manager

Pyykkö \& Saarelma Ltd

Limingantie 9

FIN-00550 Helsinki, Finland

Tel: +3589790080

Fax: +35897573630

Email: secretariat@woreal.org

Website: www.woreal.org

\section{CORRECTIONS}

We apologise for the following errors in table 4 of the paper by Wong et al (Associations between daily mortalities from respiratory and cardiovascular diseases and air pollution in Hong Kong, China. Occup Environ Med 2002;59:30-5).

- Mortality from pneumonia and influenza: 4 Pollutant model, under $\mathrm{NO}_{2}$ : "l.004 (1.017 to 1.025$)$ " should read: "1.004 $(0.984 \text { to } 1.025)^{\prime \prime}$.

- Mortality from ischaemic heart diseases 2 Pollutant model, also under $\mathrm{NO}_{2}$ : “1.022

(1.011 to 1.003$) "$ should read: "1.022 (1.011 to 1.033$)^{\prime \prime}$.

We apologise for the following error in the paper by Yassin et al (Knowledge, attitude, practice, and toxicity symptoms associated with pesticide use among farm workers in the Gaza Strip. Occup Environ Med 2002;59:387393).

The page reference at the start of the paper should be 387-393, and not 387-394. 